\title{
Optimization of coating parameters for air permeability of denim fabrics through Taguchi method
}

\author{
DOI: $10.35530 / I T .070 .03 .1564$
}

\section{REZUMAT - ABSTRACT}

\section{Optimizarea parametrilor de acoperire pentru permeabilitatea la aer a țesăturilor denim prin metoda Taguchi}

Tehnologia de acoperire este o metodă din ce în ce mai populară pentru crearea unor modele speciale și obținerea unui aspect diferit al țesăturilor denim. În funcție de proprietățile așteptate din partea țesăturilor denim, parametrii de proces ai acoperirii pot fi modificați. Este important modul în care parametrii procesului afectează caracteristicile de confort ale țesăturilor denim. Prezentul studiu are ca scop optimizarea diferiților parametri ai procesului de acoperire pentru proprietățile de permeabilitate la aer ale țesăturilor denim, folosind metoda Taguchi. Parametrii selectați pentru optimizare sunt presiunea de stoarcere, viscozitatea fluidului de acoperire, viteza de trecere a țesăturii, temperatura de uscare și desimea firelor de bătătură ale țesăturilor. Un model ortogonal L27 $\left(3^{5}\right)$ a fost ales ca plan experimental. În evaluările cu metoda Taguchi au fost utilizate analize ale raportului semnal-zgomot (S/N) și varianță (ANOVA). Rezultatele arată că desimea firelor de bătătură și viscozitatea au o influență semnificativă asupra proprietăților de permeabilitate la aer a țesăturilor denim acoperite.

Cuvinte-cheie: țesătură denim, acoperire, permeabilitate la aer, metoda Taguchi, raport S/N

\section{Optimization of coating parameters for air permeability of denim fabrics through Taguchi method}

Coating technology is an increasingly popular method for creating special designs and getting different appearance to denim fabrics. Depending on the expected properties from denim fabrics, the process parameters of coating can be changed. It is important issue how process parameters affect the comfort characteristics of denim fabrics. The present study is aimed at optimizing the various coating process parameters for the air permeability properties of denim fabrics by using Taguchi method. The parameters selected for optimization are squeeze pressure, viscosity of coating fluid, fabric passing speed, drying temperature and weft density of fabrics. An $L 27\left(3^{5}\right)$ orthogonal design was chosen as experimental plan. In the evaluations with Taguchi Method, analyses of the signal to noise ratio (S/N) and variance (ANOVA) were used. The results show that weft density and viscosity have significant influence on the air permeability properties of coated denim fabrics.

Keywords: denim fabric, coating, air permeability, Taguchi method, S/N ratio

\section{INTRODUCTION}

Denim has been widely acknowledged by all the age group throughout the world for many years. High durability, longer washing cycle and its ability to adapt to changing fashion trends and demands have made it most popular garment in the international market. Depending on growth and change in demand for denim products, denim fabric manufacturers constantly try to develop novel varieties of denim fabrics by various methods to meet consumer demands.

Fabric finishing is the last stage in the production of denim and it is where the final touch is added, and it can make a big difference in how the fabric looks, feels and wears. There are countless dry and wet finishing processes in denim garment processing like washing, bleaching, printing, coating etc. Coating is an important process for covering the surface of denim fabric with chemicals or dyestuffs in order to improve various surface properties such as waxy, oily, glossy, paper, leather, silicone, etc. Coating materials can be waxes, rubbers, latex, plastic films, resins, polyurethanes, binders or metal powders. Today several coating layers can be applied to denim fabrics to obtain different visual effects after washing treatment. In general, knife, foam and rotary screen coating methods are used to coat denim fabrics [1-4]. When considering the coating of fabrics like denim, breathability of the fabric is essential along with performance and aesthetic properties. Therefore, air permeability is an important factor in determining the comfort level of a coated fabric as it plays a significant role in transporting moisture vapors from the skin to the outside atmosphere [5]. It is thought that many parameters of coating process may affect the air permeability of the coated fabrics. Without a scientific approach, it is very difficult to assess these parameters in mill conditions. At the same time, it is quite exhaustive to determine the effects of all process parameters affecting air permeability of coated fabrics with full factorial design, because it requires a wide range of experiments, which extremely increase the experimental period and cost [6].

The present study is focused on optimizing the various coating process parameters for the air permeability properties of denim fabrics by using Taguchi's experimental design technique, a leading optimization technique reducing the experimental period and cost. Taguchi method provides the means to minimize 
the variability of products and processes in order to improve their quality and reliability. This particular design methodology has been successfully employed in a wide variety of fields, including textile engineering [7].

Yang at al. investigated the optimization of the printing process using the Taguchi method. To determine the optimum conditions for color strength and fastness, two types of multiple characteristic parameter design methods were used, including the single characteristic value conversion method and the minimummaximum selection method. As a result, the single characteristic value conversion method was proved to be more efficient compared to the minimum-maximum selection method [8]. Three factors, i.e. elastane linear density, fabric thread density and weave float were investigated by Maqsood at al. in terms of air permeability, stretch \% and recovery \% along warp and weft, using grey relational method. They found that by increasing elastane count (dtex), fabric stretch \% along warp, fabric warp-way and weft-way recovery increases, whereas fabric air permeability and stretch \% along weft decrease [9]. Nassif studied the optimization of the fabric parameters influencing the woven cotton fabrics' air permeability. As conducting the cause and effect diagram, weft yarn count, weft yarn twist factor and weft yarn density were determined as control factors influencing woven fabrics' air permeability. It was observed that the weft yarn density was the most important control factor influencing fabric air permeability followed by weft yarn count [10]. Ahmad at al. investigated the optimization of water and oil repellent finishing of cotton fabric using Taguchi based grey relational analysis. They found that the concentration of Oleophobol CPC was the most significant factor (42\%) followed by curing temperature (38\%) and the cross-linking agent Knittex FEL concentration (15\%) [11]. Mavruz and Ogulata analyzed the effect of certain yarn and fabric parameters on the bursting strength of knitted fabric, using Taguchi orthogonal design. Relaxation treatment, yarn type and loop length were chosen as the control parameters. They found that the contribution of different factors in a decreasing order was as follows: yarn type $(62.44 \%)$, relaxation treatment (34.39\%), loop length (1.63\%) and undefined parameters $(1.54 \%)$ [12]. Shabaridharan and Das studied the effect of different types of coated fabric on thermal properties of multilayered fabrics consisting of knitted fabric and through air-bonded nonwovens. Also, they analyzed the effect of pore size and porosity on thermal and evaporative resistances of coated fabrics. It was found that the mass per unit area of through air-bonded nonwoven and pore size of coated fabric were found to have significant effect on thermal and evaporative resistances of multilayered fabric ensembles [13].

\section{Fundamentals of Taguchi method}

Taguchi method is a unique and powerful optimization discipline that allows optimization with minimum number of experiments. The advantages of Taguchi method over the other methods are that numerous factors can be simultaneously optimized and more quantitative information can be extracted from fewer experimental trials [14]. Taguchi involves the stages of system design, parameters design, and tolerance design. In system design, the engineer applies scientific and engineering knowledge to produce a basic functional prototype design, this design including the product design stage and the process design stage. Since system design is an initial functional design, it may be far from optimum in terms of quality and cost. The objective of parameter design is to optimize the settings of the process parameter values for improving quality characteristics and to identify the product parameter values under the optimal process parameter values. Finally, tolerance design is used to determine and analyze tolerances in the optimal settings recommended by parameter design [6, 15-19].

Two major tools used in Taguchi's method are the orthogonal array $(\mathrm{OA})$ and the signal-to-noise ratio ( $\mathrm{S} / \mathrm{N}$ ratio). OA, which determines the optimum level for each factor and establishes the relative significance of the individual factors in terms of their main effects on the response is a matrix of numbers arranged in rows and columns. $S / N$ ratio $(\eta)$ expressed in decibels $(\mathrm{dB})$ is indicative of quality and the purpose of the Taguchi experiment is to find the best level for each operating parameter so as to maximize (or minimize) $S / N$ ratio [12, 15, 20-21].

The Taguchi method, depending on the objective, proposed three categories of quality characteristics in the analysis of $S / N$ ratio, which are nominal-the-better, larger-the-better and smaller-the-better. The three different signal-noise ratios, corresponding to $n$ experiments, are presented below:

Nominal-the-better:

$$
\begin{aligned}
S / N & =-10 \log \left[\frac{1}{n} \sum_{i=1}^{n}\left(y_{i}-m\right)^{2}\right]= \\
& =-10 \log \left[(\bar{y}-m)^{2}+S^{2}\right]
\end{aligned}
$$

Larger-the-better

$$
S / N=-10 \log \left[\frac{1}{n} \sum_{i=1}^{n} \frac{1}{y_{i}^{2}}\right]=
$$

Smaller-the-better

$$
S / N=-10 \log \left[\frac{1}{n} \sum_{i=1}^{n} y_{i}^{2}\right]=-10 \log \left(\bar{y}^{2}\right)
$$

where $S$ denotes the standard deviation; $y_{i}-$ the data obtained from experiments; $n$ represents the number of experiments [5]. Regardless of the category of the quality characteristic, a greater $S / N$ ratio corresponds to better quality characteristics.

Taguchi methodology for optimization can be divided into four phases: planning, conducting, analysis and validation. Each phase has a separate objective and contributes towards the overall optimization process [5]. To summarize, the parameter design of the Taguchi method includes the following steps: (1) define the problem and the objective; (2) identification of control factor and levels; (3) selection of the appropriate 
orthogonal array and assignment of design parameters to the orthogonal array; (4) conducting of the experiments based on the arrangement of the orthogonal array; (5) analysis of the experimental results using the S/N and ANOVA analyses; (6) selection of the optimal levels of design parameters; and (7) verification of the optimal design parameters through the confirmation experiment [15].

\section{MATERIALS AND METHODS}

Taguchi parameter design analysis was performed with Minitab Version 16.0 software package that is a computer program designed to perform basic and advanced statistical functions. In this study; squeeze pressure, viscosity of coating fluid, fabric passing speed, drying temperature and weft density were selected as control factors affecting the air permeability of denim fabrics. After determining the control factors, the levels of each factor were determined. Each of the control factors was evaluated with three levels. The working conditions of coating machine were taken into consideration in order to determine the factors and levels. The five process parameters or factors for convenience are represented by the letters A-E. The factors (A-E) and levels of each factor are listed in table 1.

Table 1

\begin{tabular}{|c|c|c|c|c|}
\hline \multicolumn{5}{|c|}{$\begin{array}{c}\text { CONTROL FACTORS AND LEVELS FOR } \\
\text { THE EXPERIMENTAL DESIG }\end{array}$} \\
\cline { 3 - 5 } Code & \multirow{2}{*}{ Factors } & $\mathbf{3}$ & $\mathbf{2}$ & $\mathbf{3}$ \\
\hline A & Weft density (picks/cm) & 14 & 17 & 20 \\
\hline B & Drying temperature $\left({ }^{\circ} \mathbf{C}\right)$ & 120 & 140 & 160 \\
\hline C & Viscosity (dPa.s) & 30 & 50 & 70 \\
\hline D & Squeeze pressure (bar) & 3 & 5 & 7 \\
\hline E & Fabric passing speed (m/min) & 10 & 20 & 30 \\
\hline
\end{tabular}

In this study, an L27 $\left(3^{5}\right)$ OA table was selected, as shown in table 2 . With five factors, each having three levels, a total of $243\left(3^{5}\right)$ full factorial experiments would be required to explore all possible factor-level combinations and, the cost and effort of such experiments would be quite large. However, with this experimental design of L27 $\left(3^{5}\right)$ OA, only 27 experiments were required.

After determining the control factors and their levels, three denim fabric samples were manufactured with 3/1 Z twill structure. Ne 8.2/1 ring yarns were used as the warp yarn with a density of 17 ends/cm for all fabric samples. The weft density of the denim fabrics was used as control parameter and $\mathrm{Ne} 10.4 / 1$ ring core-spun yarns (\%95 cotton and \%5 Elastane-70 dtex) were used as weft yarn with three different density $(14,17$ and 20 picks $/ \mathrm{cm})$. The coating of the denim fabrics was applied by the Rotary Screen Coating Method, which is the deposition of a coating material on a substrate through a mesh screen by squeezing. A standard coating pat used in the mill was used for the coating of the denim fabrics.
All coated denim samples were conditioned for $24 \mathrm{~h}$ at $20^{\circ} \mathrm{C}$ and $65 \%$ relative humidity prior to air permeability testing. Air permeability of the coated denim fabrics were evaluated according to the CSN EN ISO 9237 standard, using the Textest FX 3300 air permeability tester at a constant pressure drop of $100 \mathrm{~Pa}$ (20 $\mathrm{cm}^{2}$ test area). Ten samples were tested each sample and expressed as $\mathrm{mm} / \mathrm{s}$.

In determining the optimum coating conditions for air permeability of denim fabrics, Taguchi's parameter design approach was used to plan, analyze, and confirm the experiments. First, it was calculated the $S / N$ ratios of repeated experimental results obtained from the experimental design using L27 orthogonal array. Then, it was determined the optimum level for each of the coating parameters. Next, a statistical analysis of variance (ANOVA) was performed to see which process parameters are statistically significant. Finally, improving rate obtained from using optimum factor levels was calculated by compared to the selected initial design.

\section{RESULTS AND DISCUSSION}

In the Taguchi optimization method, analysis of response depends upon whether smaller or larger value of the response is desired. In this study, the air permeability was classified under the response type "larger is better", because the high value of air permeability is a desirable feature in terms of comfort. The formula used for the calculation of the $S / N$ ratio is given (2) in the introduction of the paper and the calculated $S / N$ ratios for air permeability are given in table 2.

In the Taguchi method, another step is to determine the average effect of each factor on the multiple quality characteristic at different levels. This is equal to the sum of all $S / N$ ratios corresponding to a factor at a particular level divided by the number of repetitions of the factor level [5]. The factor levels corresponding to the maximum average effect are selected as the optimum level. For air permeability values of coated denim fabrics, the average factor effect is shown in table 3 , and the main effects plotted for $S / N$ ratio are shown in figure 1 . The delta value (table 3 ) was calculated by subtracting the largest value from the

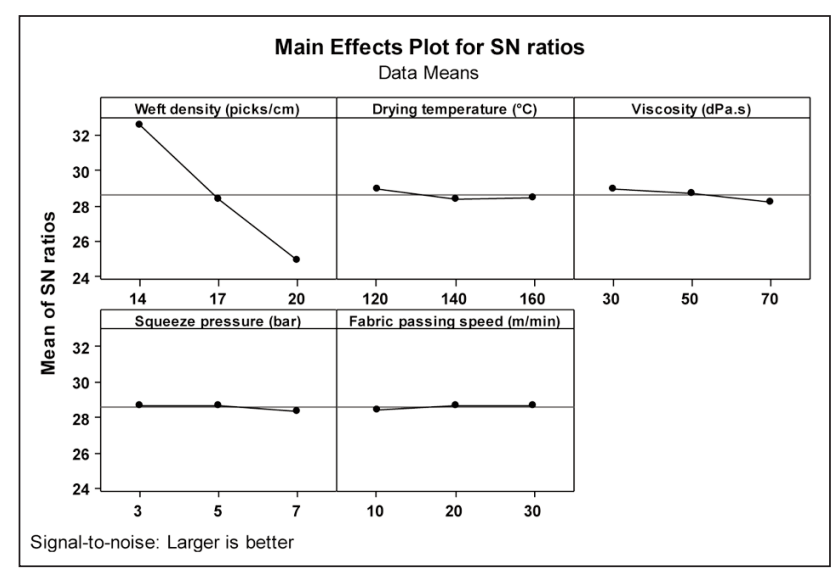

Fig. 1. Main effects plot for $\mathrm{S} / \mathrm{N}$ of air permeability output 


\begin{tabular}{|c|c|c|c|c|c|c|c|}
\hline \multicolumn{8}{|c|}{$\begin{array}{l}\text { EXPERIMENTAL LAYOUT USING AN L }{ }_{27}\left(3^{5}\right) \\
\text { ORTHOGONAL ARRAY TABLE }\end{array}$} \\
\hline \multirow{2}{*}{ Order } & \multicolumn{5}{|c|}{ Parameters } & \multirow{2}{*}{$\begin{array}{l}\text { Average air } \\
\text { permeability } \\
\text { value, } \mathrm{mm} / \mathrm{s}\end{array}$} & \multirow{2}{*}{$\begin{array}{l}\mathrm{S} / \mathrm{N} \text { ratio, } \\
\mathrm{dB}\end{array}$} \\
\hline & A & B & C & D & E & & \\
\hline 1 & 1 & 1 & 1 & 1 & 1 & 45.18 & 33.06 \\
\hline 2 & 1 & 1 & 1 & 1 & 2 & 45.32 & 33.10 \\
\hline 3 & 1 & 1 & 1 & 1 & 3 & 49.12 & 33.79 \\
\hline 4 & 1 & 2 & 2 & 2 & 1 & 40.19 & 32.07 \\
\hline 5 & 1 & 2 & 2 & 2 & 2 & 43.09 & 32.65 \\
\hline 6 & 1 & 2 & 2 & 2 & 3 & 43.36 & 32.73 \\
\hline 7 & 1 & 3 & 3 & 3 & 1 & 35.28 & 30.92 \\
\hline 8 & 1 & 3 & 3 & 3 & 2 & 40.39 & 32.11 \\
\hline 9 & 1 & 3 & 3 & 3 & 3 & 42.10 & 32.46 \\
\hline 10 & 2 & 1 & 2 & 3 & 1 & 27.60 & 28.72 \\
\hline 11 & 2 & 1 & 2 & 3 & 2 & 26.91 & 28.53 \\
\hline 12 & 2 & 1 & 2 & 3 & 3 & 26.79 & 28.47 \\
\hline 13 & 2 & 2 & 3 & 1 & 1 & 23.31 & 27.33 \\
\hline 14 & 2 & 2 & 3 & 1 & 2 & 24.83 & 27.82 \\
\hline 15 & 2 & 2 & 3 & 1 & 3 & 26.77 & 28.53 \\
\hline 16 & 2 & 3 & 1 & 2 & 1 & 26.33 & 28.39 \\
\hline 17 & 2 & 3 & 1 & 2 & 2 & 28.59 & 29.10 \\
\hline 18 & 2 & 3 & 1 & 2 & 3 & 25.96 & 28.25 \\
\hline 19 & 3 & 1 & 3 & 2 & 1 & 19.74 & 25.86 \\
\hline 20 & 3 & 1 & 3 & 2 & 2 & 17.25 & 24.72 \\
\hline 21 & 3 & 1 & 3 & 2 & 3 & 16.28 & 24.22 \\
\hline 22 & 3 & 2 & 1 & 3 & 1 & 17.59 & 24.90 \\
\hline 23 & 3 & 2 & 1 & 3 & 2 & 17.73 & 24.97 \\
\hline 24 & 3 & 2 & 1 & 3 & 3 & 16.81 & 24.50 \\
\hline 25 & 3 & 3 & 2 & 1 & 1 & 17.02 & 24.61 \\
\hline 26 & 3 & 3 & 2 & 1 & 2 & 17.94 & 25.06 \\
\hline 27 & 3 & 3 & 2 & 1 & 3 & 18.33 & 25.25 \\
\hline
\end{tabular}

lowest from among the values in each row. A higher delta value means that the difference at the selected level for a given factor is highly pronounced and, in turn, the level change of this factor has an impact on the air permeability properties of coated denim fabric. Based on the $S / N$ ratios, the most effective input parameter is weft density (A) and second effective
RESPONSE TABLE FOR THE S/N RATIO OF AIR PERMEABILITY OUTPUT

\begin{tabular}{|c|c|c|c|c|c|}
\hline \multirow{2}{*}{ Factors } & \multicolumn{5}{|c|}{ Average S/N, dB } \\
\cline { 2 - 6 } & Level 1 & Level 2 & Level 3 & Delta & Rank \\
\hline A & $32.54^{*}$ & 28.35 & 24.90 & 7.64 & 1 \\
\hline B & $28.94^{*}$ & 28.39 & 28.46 & 0.55 & 3 \\
\hline C & $28.89^{*}$ & 28.68 & 28.22 & 0.68 & 2 \\
\hline D & $28.73^{*}$ & 28.67 & 28.40 & 0.33 & 4 \\
\hline E & 28.43 & 28.67 & $28.69^{*}$ & 0.26 & 5 \\
\hline
\end{tabular}

* Optimum parameter level

input parameter is viscosity $(C)$. The highest level of weft density (A) factor is at level 1 and air permeability value decrease with the increasing weft density, as expected (figure 1). This decrease in air permeability may be attributed to the decreasing pore size which depends on the increasing of weft density. Also, the highest level of viscosity factor $(C)$ is at level 1 and air permeability value decrease with the increasing viscosity. In another word, the viscosity increase negatively affects the air permeability values of the fabrics. The combination satisfying the maximum air permeability value (A1B1C1D1E3) was determined by choosing the highest $S / N$ ratio for each factor.

The analysis of variance (ANOVA) is performed on $S / N$ ratios to see which process parameters are statistically significant and to obtain the percentage contribution of each of the factors. The contribution ratio is calculated from the ratio of the sum of squares (SS) of each factor to total SS value. The bigger this value on the output of that parameter is understood to be effective at that rate. Table 4 lists the analysis of variance for $S / N$ ratio of air permeability and the contribution ratio of each parameter to air permeability. In the table, weft density (A), has the highest value of $96.6 \%$ in contribution and this factor has significant effect on the air permeability properties of coated denim fabrics. A small variation for the weft density factor with a high percent contribution will have a great influence on the air permeability. Also, viscosity (C) parameter has significant effect on the air permeability values of coated denim fabric and the contribution of viscosity value is $0.79 \%$ for air

ANOVA TABLE FOR S/N RATIO OF AIR PERMEABILITY OUTPUT

\begin{tabular}{|c|c|c|c|c|c|c|}
\hline Factor & df & Sum of squares & Mean square & F-value & P & Percentage contribution (\%) \\
\hline A & 2 & 263.767 & 131.883 & 474.00 & 0.000 & 96.6 \\
\hline B & 2 & 1.631 & 0.815 & 2.93 & 0.082 & 0.59 \\
\hline C & 2 & 2.154 & 1.077 & 3.87 & 0.043 & 0.79 \\
\hline D & 2 & 0.553 & 0.277 & 0.99 & 0.392 & 0.20 \\
\hline E & 2 & 0.384 & 0.192 & 0.69 & 0.516 & 0.14 \\
\hline Residual & 16 & 4.452 & 0.278 & & & 0.63 \\
\hline Total & 26 & 272.941 & & & & \\
\hline
\end{tabular}


permeability output. Furthermore, it can be seen that the ANOVA has resulted in around $0.63 \%$ of error contribution due to interaction effect. Thus, the optimization is also affected by the interaction between the factors.

\section{Confirmation test for air permeability output}

The confirmation experiment is the final step of the design of an experiment. The purpose of the confirmation experiment is to predict and verify the conclusions drawn during the analysis phase. The confirmation experiment is performed by conducting a test with optimal settings of the factors and levels previously evaluated [22]. The predicted value of the multiple $S / N$ ratio at the optimum level is calculated as:

$$
\eta_{0}=\eta_{m}+\sum_{i=1}^{j}\left(\eta_{i}-\eta_{m}\right)
$$

where, $\eta_{m}$ is total mean of $S / N$ ratio, $j$ - the number of factors, and $\eta_{i}-$ the multiple $S / N$ ratios corresponding to optimum factor levels. The predicted $S / N$ ratio of optimum design is found to be $33.39 \mathrm{~dB}$ for air permeability. If the $S / N$ is known and we want to learn about the result expected that will make the $S / N$, the procedure is to back-transform $S / N$ to find the performance value expected [12]. When the predicted $S / N$ was placed into Formula 2, the predicted air permeability values of the optimum design was obtained as $46.07 \mathrm{~mm} / \mathrm{s}$.

The confirmation experiment was not performed with optimum combination (A1B1C1D1E3), since this combination is in the experiment design (table 2). As shown in table 2, the $S / N$ and average air permeability value for optimum conditions are 33.79 and 49.12 , respectively. These results are very close to that predicted by Taguchi design. Table 5 shows the comparison of the predicted air permeability with the experimental air permeability using the optimal coating parameters.

The confidence interval $(\mathrm{Cl})$ of predicted $S / N$ value for the optimum factor level combination at $95 \%$ confidence band is calculated to determine whether the results of the confirmation experiments are reasonable or not. The $\mathrm{Cl}$ is calculated by Eq. 5 :

$$
C l=\sqrt{F_{\alpha ; 1, D F_{M S e}} \cdot M S e \cdot\left(\frac{1+m}{N}+\frac{1}{n_{r}}\right)}
$$

In Eq. $4, F_{\alpha}$ is the value of $F$ table, $\alpha$ - the error level, $D F_{M S e}$ - the degree of freedom of mean square error, $m$ - the degrees of freedom of $j$ factors, $N$ - the number of the total experiments and $n_{r}$ - the number of repetitions in the confirmation experiments. For the present study, $\mathrm{Cl}$ was found \pm 0.42 and this means that the experimental $S / N$ ratio for optimum conditions is located in the confidence interval, as shown Eq. 6. Therefore, the optimal air permeability can be obtained under the above-mentioned coating conditions.

RESULTS OF THE CONFIRMATION EXPERIMENT FOR AIR PERMEABILITY

\begin{tabular}{|c|c|c|c|} 
& \multirow{2}{*}{$\begin{array}{c}\text { Starting } \\
\text { coating } \\
\text { parameters }\end{array}$} & \multicolumn{2}{|c|}{ Optimal coating parameters } \\
\cline { 3 - 4 } & Prediction & Experiment \\
\hline Optimal level & A1B1C1D1E1 & A1B1C1D1E3 & A1B1C1D1E3 \\
\hline Air permeability & 45.18 & 46.07 & 49.12 \\
\hline S/N ratio & 33.05 & 33.39 & 33.79 \\
\hline
\end{tabular}

Predicted optimum $\mathrm{S} / \mathrm{N}-\mathrm{Cl}<$ Experimental optimum $S / N<$ Predicted optimum $S / N+C l$

$$
\begin{aligned}
33.39-0.42 & <33.79<33.39+0.42 \\
32.97 & <33.79<33.81
\end{aligned}
$$

Finally, first trial (A1B1C1D1E1) is selected as the initial design $(S / N=33.05 \mathrm{~dB})$, and the difference $(d)$, is obtained between the $S / N$ ratio of the predicted optimal design $(S / N)_{0}$ and the $S / N$ ratio of the selected design $(S / N)_{i}$ as shown below:

$$
\begin{gathered}
d=(S / N)_{0}-(S / N)_{i} \\
d=-10 \log L_{0}-\left(-10 \log L_{i}\right) \\
d=33.39-33.05=0.34 \mathrm{~dB}
\end{gathered}
$$

Improving rate obtained from using optimum factor levels, is achieved by the following equation (8):

$$
\begin{gathered}
L_{i} / L_{o}=10^{d / 10} \\
L_{i} / L_{o}=10^{0.34 / 10}=1.08 \text { times }
\end{gathered}
$$

According to this result, the air permeability of coated denim fabrics under optimum conditions is found to be improved 1.08 times.

\section{CONCLUSIONS}

In this study, the optimum coating conditions was determined for the air permeability of denim fabrics by Taguchi method. An optimum coating parameter combination for the maximum air permeability was obtained by using the analysis of signal-to-noise $(S / N)$ ratio. Based on the $S / N$ ratio, the optimum levels of the coating parameters for air permeability are 14 picks/cm weft density, $140^{\circ} \mathrm{C}$ drying temperature, 30 dpas viscosity, 3 bar squeeze pressure, $30 \mathrm{~m} / \mathrm{min}$ fabric passing speed. This combination was included in the test plan as Experiment No. 3. The level of importance of the process's parameters is determined by using ANOVA. As a result of ANOVA test, it was determined that air permeability can be improved significantly with weft density and viscosity for coated denim fabrics. The contribution ratios of weft density and viscosity are $96.6 \%$ and $0.79 \%$ on air permeability, respectively. This means that air permeability can be largely improved by the controlled change of weft density. In addition, a confirmation test was performed to see the improvement in the air permeability of the fabrics. The improvement of air permeability from the initial coating parameters to the 
predicted optimal coating parameters was found about 1.08 times. Moreover, it is seen that Taguchi method is a promising approach for optimizing coat- ing process parameters of denim fabrics to meet maximum air permeability, with a very limited number of experiments and short time.

\section{BIBLIOGRAPHY}

[1] Paul, R. Denim manufacture, finishing and applications, In: Woodhead Publishing Series in Textiles, Number 164, Elsevier, 2015, pp. 1-599.

[2] Sen, A. K. Coated textiles principles and applications, In: Copyright 2008 by Taylor and Francis Group, LLC, International Standard Book Number-13: 978-1-4200-5345-6, 2008, pp. 1-230.

[3] Smith, W. C. Smart textile coatings and laminates, In: Woodhead Publishing Series in Textiles: Number 90, The Textile Institute and Woodhead Publishing Limited, CRC Press LLC, 2010, pp. 1-304.

[4] Giessmann, A. Coating substrates and textiles, In: A Practical Guide to Coating and Laminating Technologies, Coatema Coating Machinery GmbH, Dormagen, Germany, 2012, pp. 1-243.

[5] Ogulata, R. T., Mezarcioz, S. M. Optimization of air permeability of knitted fabrics with the Taguchi approach, In: The Journal of The Textile Institute, 2011, Vol. 102, No. 5, pp. 395-404.

[6] Gunes, S., Manay, E., Senyigit, E. and Ozceyhan, V. A Taguchi approach for optimization of design parameters in a tube with coiled wire inserts, In: Applied Thermal Engineering, 2011, 31, pp. 2568-2577.

[7] Lai, H., Chang, Y. and Chang H., A robust design approach for enhancing the feeling quality of a product: a car profile case study, In: International Journal of Industrial Ergonomics, 2004, Volume 35, Issue 5, pp. 445-460.

[8] Jung, J. J., Kim, S., Park, C. K. Optimization of digital textile printing process using Taguchi method, In: Journal of Engineered Fibers and Fabrics, 2016, Volume 11, Issue 2, pp. 51-59.

[9] Maqsood, M., Hussain, T., Ahmad, N., and Hawab Y. Multi-response optimization of mechanical and comfort properties of bi-stretch woven fabrics using grey relational analysis in Taguchi method, In: The Journal of The Textile Institute, 2017, 108:5, pp. 794-802.

[10] Nassif, G.A. Using Taguchi methodology to optimize woven fabrics air permeability, In: Journal of Textile Science \& Engineering, 2017, Volume 7, Issue 6, pp. 2-4.

[11] Ahmad, N., Kamal, S., Raza, Z. A., Hussain, T., Anwar, F. Multi-response optimization in the development of oleohydrophobic cotton fabric using Taguchi based grey relational analysis, In: Applied Surface Science, 2016, 367, pp. 370-381.

[12] Mavruz, S., Ogulata, R.T. Taguchi approach for the optimisation of the bursting strength of knitted fabrics, In: Fibres \& Textiles in Eastern Europe 2010, Vol. 18, No. 2 (79) pp. 78-83.

[13] Shabaridharan K., Das, A. Analysis of thermal properties of multilayered fabrics by full factorial and Taguchi method, In: The Journal of The Textile Institute, 2014, Vol. 105, No. 1, pp. 29-41.

[14] Pundir, R., Chary, G.H.V.C., Dastidar, M.G. Application of Taguchi method for optimizing the process parameters for there moval of copper and nickel by growing Aspergillus sp., In: Water Resources and Industry, 2016, http://dx.doi.org/10.1016/j.wri.2016.05.001.

[15] Yang, W. H., Tarng, Y. S. Design optimization of cutting parameters for turning operations based on the Taguchi method, In: Journal of Materials Processing Technology, 1998, 84, pp. 122-129.

[16] Babayiğit, B., Şenyiğit, E. Design optimization of circular antenna arrays using Taguchi method, In: Neural Computing \& Applications, 2017, vol. 28, pp.1443-1452.

[17] Babayiğit, B., Şenyiğit, E., Mumcu, G. Optimum broadband E-patch antenna design with Taguchi method, In: Journal of Electromagnetıc Waves And Applications, 2016, vol. 30, pp. 915-927.

[18] Şenyiğit, E., Aydın, M.E., Düğenci, M., Zeydan, M. Heuristic-based neural networks for stochastic dynamic lot sizing problem, In: Applied Soft Computing, 2013, vol. 13, no. 3, pp. 1332-1339.

[19] Yildiz, Y.Ş., Şenyiğit, E., İrdemez, Ş. Optimization of specific energy consumption for Bomaplex Red Cr-L dye removal from aqueous solution by electrocoagulation using Taguchi-neural method, In: Neural Computing \& Applications, 2013, vol. 23, no. 3-4, pp. 1061-1069.

[20] Khosla, A., Kumar, S., Aggarwalk, K. K. Identification of strategy parameters for particle swarm optimizer through Taguchi method, In: J Zhejiang Univ SCIENCE A, 2006, 7(12):1989-1994.

[21] Ionesi, S. D., Dumitraş, C., Fangueıro, R., Ursache, M., Cıobanu, L., Dulgherıu, I. Evaluation of impact behaviour of composite materials using Taguchi method, In: Industria Textila, 2014, vol. 65, nr. 3, pp. 153-157.

[22] Tosun, N., Cogun, C. and Tosun, G. A study on kerf and material removal rate in wire electrical discharge machining based on Taguchi method, In: Journal of Materials Processing Technology, 2015, 152, pp. 316-322.

\section{Authors:}

\section{SÜMEYYE ÜSTÜNTAĞ HÜSEYIN GAZI TÜRKSOY}

Department of Textile Engineering, Erciyes University, 38039, Kayseri, Turkey e-mail: sumeyyeustuntag@erciyes.edu.tr; hgazi@erciyes.edu.tr

Corresponding author:

\section{SÜMEYYE ÜSTÜNTAĞ}

sumeyyeustuntag@erciyes.edu.tr 